\title{
The Role of Home Gardens in Household Food Security in Eastern Cape: A Case Study of Three Villages in Nkonkobe Municipality
}

\author{
Ogundiran Oluwasola Adekunle ${ }^{1}$ \\ ${ }^{1}$ Department of Agricultural Economic, Extension and Rural Development, University of Fort Hare, Alice 5700, \\ South Africa \\ Correspondence: Ogundiran Oluwasola Adekunle, Department of Agricultural Economic, Extension and Rural \\ Development, University of Fort Hare, Alice 5700, South Africa. Tel: 27-083-570-3601. E-mail: \\ ogundiranoluwasola@yahoo.com
}

Received: May 9, 2013 Accepted: June 13, 2013 Online Published: September 15, 2013

doi:10.5539/jas.v5n10p67 URL: http://dx.doi.org/10.5539/jas.v5n10p67

\begin{abstract}
The South African government has committed to halving poverty between 2004 and 2014 and achieving household food security is their major objective. Access to food and water is perhaps unlike other areas of delivery, since they are essential to well-being and human development. The Eastern Cape Province is the second largest provinces in South Africa, but yet second poorest province. This study looks at the role of home gardens in enhancing food security around Nkonkobe Municipality. The specific objectives were to; investigate what people produce in their gardens; assess how much produce they obtain from their gardens; investigate household source of food. This study was carried out to understand the role of home gardens in addressing household food security in rural areas of Nkonkobes Municipality. A study was carried out among rural households in rural areas of Nkonkobes Municipality, to determine the role of home gardening on household food security. Simple random sampling was used to obtain a study population of 60 households, to whom an interview schedule and an observation checklist was administered. These were achieved through personal interviews in three area 20 respondents from each village. Primary data were obtained through structured questionnaire in those areas and data obtained were analyzed quantitatively. Results obtained showed that home gardening plays a significant role in food security of rural households. Households, therefore, should be empowered and encouraged to improve their practice of home gardening to realize food security. Findings of this study will be useful to governmental and non-governmental bodies involved in promoting food security in the rural households.
\end{abstract}

Keywords: home gardening, household, importance of home gardening, food security and eastern cape

\section{Introduction}

\subsection{Background of the Study}

Today the world faces a fundamental challenge of ensuring that millions of households living in poverty have access to enough food to maintain a healthy life. Over the years Africa has been looking for ways to solve the food insecurity problem and most African leaders have taken cognizance of this challenge (Omotesho et al., 2007). Most of the developing countries, agriculture is an essential sector of the proportion of the agricultural activities that take place in rural areas since agriculture has been said to be the backbone in rural areas and many countries rely upon it for survival (Todaro \& Smith, 2000). Numerous attempts in South Africa to implement gardens programs often fail to improve food security of the poor (Moorhead \& Wolmer, 2001). Home gardens are considered a community's most adaptable and accessible land resource and are an important component in reducing vulnerability and ensuring food security (Buchmann, 2009). Home gardens form an integral part of urban and rural livelihoods. For many generations, small plots of land near the homestead have been used as home gardens (Sigot, 2001). They are sites that people grow not only staple foods but where they also cultivate plants for income and for medicine (Gari, 2004; Nordic, 2005).

Thus home gardens are important to families because they provide income and sustenance throughout the year from the diversity of crops contained within them which are harvested at different times. Mula and Gayao (1991) assert that the cultural value attached to home gardens has been reinforced by their important contribution to household food security over the past 50 year. In contemporary South Africa, income is the principal determinant of household food security (Kirsten, May, Hendriks, Lyne, Machete, \& Punts, 2003). For monetary income South 
African black rural households mainly depend on sources other than farming, including claims against the state, wage earnings, remittances by kin who live and work elsewhere, and petty trade (Carter \& May, 1999; Crookes, 2003).

Smallholder farmers utilizing many indigenous varieties and sustainable agriculture systems are said to have an enormous potential to support HIV/AIDS afflicted households and their communities in many ways. Home gardens then fill major gaps in the food supply. However, members of the household with direct access to a variety of nutritionally rich foods, which include roots, tubers, green leafy vegetables, condiments, nuts, legumes, fruits and livestock products (FAO, 2001). Whereas the practice of home gardening is a supplementary food production system and not the household's primary source of food, it is increasingly becoming popular with households but mostly getting attention from development agencies (Action Aid, 2005; Nordin, 2005; HSRC, 2003). In South Africa, as in many other developing countries, food security is a concern among poor households, particularly in the rural areas; a significant number may be considered resource poor and therefore food insecure although South Africa is considered to be food self sufficient (Mc Lachlan \& Kuzwayo, 1997).

According to (McLachlan \& Kuzwayo, 1997) socio-economic conditions play a more important role in food security. This is because ensuring access to food at the household level depends not only on secure food supplies, but also on stable demand or purchasing power. If families are unable to grow or purchase enough food, and social welfare nets are absent or ineffective, there may be hunger. This is the case in many South African societies as it is estimated that $39 \%$ of the South African population is vulnerable to food insecurity (Mgijima, 1999). Agriculture improves the nutritional status of households, but only when production generated substantial monetary income, or when it enables a substantial reduction in household food expenditure. Smallholder are the potential drivers of Agricultural development in less develop regions (Mathethe, 1999) while Delgado 1995:165 argue that "smallholder Agriculture is important to employment, human welfare and political stability in sub Saharan Africa to be either ignored or treated as just another small adjusting sector of a market economy. According to Koyenikan (2007), home gardening is an important method that can be used for food production but yet neglected a lot as an aspect of food production system over time. Musotsi, Sigot, and Onyango (2008) mention that for the majority of people in the developing world gardening remains the most important method of food production. Daily food requirement by household members are needed for better nutrition and health. Home gardens play a significant role to household food security. According to Monde et al. (2006), also said home gardening has been the since rural people have shifted from field cropping to home gardens for the past two decades.

\subsection{Purpose and Objective}

The purpose of the study is to investigate the role of home gardens in enhancing household food security in Nkonkobe Municipality, Eastern Cape, South Africa. The specific objective of this study was to investigate what people produce in their gardens; assess how much produce they obtain from home gardens; investigate when these products are available to these household.

\subsection{Review of Related Literature}

South African agriculture is characterized by dual sector, a subsistence agricultural sector that is largely black farmers and on the other a commercial sector which is largely white farmers. According to Aliber and Hart (2009), the black farming sector in South Africa appears to contribute rather minimally to overall agricultural outputs in South Africa. Actually, for anyone food security depends not only on availability of sufficient food supply, but also on sustainability of permanent access to food (Sen, 1981; Thrupp \& Megateli, 1999; Gladwin et al., 2001). Home gardens contribute to agricultural production, especially food production, more than has been generally recognized. According to Moyo (2003), agriculture is a core sector for food security, since it provides not only food to different households, raw materials, employment and foreign exchange as well as other essential resources for economic development. Therefore, there is a great role that is being played by agriculture in ensuring food security in South Africa since in this way households get to supplement their household food supplies, but there are also shortcomings associated with this sort of farming sector and the often marginal conditions in which agriculture is practiced (Aliber \& Hart, 2009). According to Koyenikan et al. (2007), households own home gardens since there are benefits attained such as increment of food production, improvement of household health and nutrition, generation of income and make use of available of space of land.

Home gardens refer to the traditional land use system around a homestead where several species of crop and vegetables are grown and maintained by the household members and their products are primarily intended for family consumption and utilization (Gautan et al., 2004). Home gardens are traditional sources of food and nutrition and therefore are important contributors to food security and livelihoods of farming communities in many countries. These gardens have been important sources of food, fodder, fuel, medicines, spices, herbs, flowers, 
construction of materials and income in many countries and also are important means of on-farm conservation of a wide range of unique genetic resources for food and agriculture (Gautan et al., 2004). According to Marsh (2007), home gardens have multiple potential benefits and they are vital such as a direct increased access to nutritious food by food insecure households. Home gardening contributes to food security by providing food that can be utilized by households on a daily basis. Home gardening can be done using only the available local planting material, green manures, fencing and indigenous pest control methods without any virtually economic resources (Marsh, 2007). About $852 \mathrm{~b}$ million men, women, children throughout worldwide are chronically hungry due to extreme poverty, while up to 2 billion people lack food security intermittently due to varying degree of poverty (Omotesho et al., 2007). Agriculture plays a vital role in household food security since it has to provide food directly through subsistence farming create jobs and generate income through commercialization (DAFF, 2007).

Household food security can be achieved since the agricultural sector is growing and the primary channel for attaining it (Machete, 2004). Agricultural activities make a positive contribution to household nutrition, which suggests that designing effective programmes for improving agricultural productivity in the less developed areas of South Africa could have a potentially positive impact on household and child nutrition status (Kirsten et al., 1998). According to Monde et al. (2006) poverty and food insecurity problems are more dominant in South African rural areas also mentions that in the research conducted, about $80 \%$ of rural earned below the poverty line. Therefore there is great dependency on external economic activities, especially state grants for a means of living. Therefore home gardens are known as the best method of supplementary food production system for a household and can be regarded as a source of food, and home gardening is one of the strategies that has the potential of enhancing food security for the poor (Mutotsi et al., 2006; Marsh, 2007).

Food security is defined varies by researcher, according to World Health Organization (2012), a fundamental element of community's health is food security. Food security was agreed by the World Food Summit of 1996 to take place when there is access by all people at all times to sufficient, nutritionally adequate and safe food for an active and healthy life WHO (2012). Labadarios, D., Davids, Y. D., Mchaza, Z. And Weir Smith, G. (2009), mention that there are four different levels that food insecurity may take place namely: the national level, regional level, community level and household level. South Africa is a country that is known to be food secure at national level, but at household level food insecurity does exist largely (Ladzani, 2009). According to Labadarios et al., (2009), food security at national level occurs when the country "is able to manufacture, import, retain and sustain food needed to support its population with minimum per capita nutritional standards".

Food security status at national level is determined using two major indicators i.e.) the measure of projected food supplies (calculated as domestic production (Gross Domestic Product (GDP) that also includes farming, plus commercial imports minus non-food uses as well as) the measure of the nutritious food supply (i.e. which is measured using the difference between projected food supplies and the amount of food needed to support the nation with individuals who earn the least amount of money) (Labadarious et al., 2009). Food security at community level is define as a situation whereby the community residents can obtain safe, culturally acceptable, nutritionally adequate diet through sustainable food system that maximises self-reliance in the community as well as social justice (Labadarios et al., 2009). The location of the community (rural, close or further way from the basic servicers used to produce food and access health services), the culture and social norms, health knowledge, attitude, beliefs, practice and resources of the community and lastly the income and education level of the community, these are the indicators used to determine the food security status of the community (Labadarious et al., 2009). Food security at household level takes place when there is food availability as well as access to food by a household (Labadarious et al., 2009). According FANRPAN (2006), hunger and malnutrition in South Africa is not caused by the shortage of food rather than the inadequate access to food by certain categories of individuals and households within the population. Women and children are said to be more vulnerable to food insecurity. Masuku and Sithole (2009), state that there are three distinct variable of food security and they also have different measures: food production and food supply which is a measure of food availability; the level of income which is a measure of food access and nutrition, health and care giving which is a measure of food utilization.

\section{Methodology}

\subsection{Description of the Study Area}

The Nkonkobe IDP (2010/11) revealed that in 2000 Nkonkobe Municipality was established. Nkonkobe Municipality is the second largest local municipality covering $3725 \mathrm{~km}^{2}$ and making up R63 of the surface areas of the Amatole District Municipality. "Nkonkobe municipality is a countryside municipality that sits on the foot of the ever imposing and majestic mountain range of the winter berg (Iintabaze Nkonkobe)". Nkonkobe Municipality is located in the Eastern Cape which is the second largest provinces of South Africa and also regarded as the 
poorest. It is one of the eight local municipalities under the Amatole District Municipality of the Eastern Cape. The Amatole, which means "the calves of the Drakensberg" in Xhosa, is a municipal district which lies in the central coastal portion of the Eastern Cape. This is the pastoral way of life that the rural Xhosa communities who still graze their colourful Nguni cattle on her foothills today.

Access to the Amatole district is served by the East London Airport, the East London river port, N2 and N6 national roads and a rail network (Nkonkobe Municipality, 2006). According to Nkonkobe Municipality (2007), Nkonkobe Municipality is bordered by the Nxuba, Lukanji, Makana and Municipality to the west as well as the Amahlathi Municipality to the east. The major towns are Alice, Fort Beaufort, Hogs back, Balfour, Middle drift and Seymour. The municipality has a predominantly rural population and has a total of twenty-one wards with forty-one municipal councils (Hule, 2010).

\subsection{Sampling Procedure}

Random sampling method was used which implies that no special sub-group of the population is particularly favoured in the sample selection. In addition it implies that the possibility of any member being selected does not depend on any other member of the population. Purposive sampling was used to avoid gender, distance and roadside biases. The samples were taken from the three major areas: Alice, Fort Beaufort and Middle drift of Nkonkobe Local Municipality

\subsection{Data Analysis Method}

For this study a qualitative and quantitative approaches were used:

To pursue the objectives of this study, field surveys were used to provide the primary data. The study was carried out in rural areas of Eastern Cape Province. A random stratified sampling method was used to draw representative samples from 3 villages in Nkonkobe Municipality, 30 respondents from each village. The structured questionnaire was chosen, as satisfactory method to fulfil the study purpose. Structured questionnaire was prepared and administered to the sampled respondents, by face to face interviews. Existing literature on role of households in food security was reviewed. The conditions in the study areas are sufficiently household representative for the findings of this research to be applicable, with some generalization and conclusion, to rural area. The data from completed questionnaire were used for the analysis. Using a widely available and well tested package program Statistical Package for the Social Sciences (SPSS 11.0 Windows). Excel statistical program was used for some descriptive explanations.

\section{Result and Discussion}

The study findings seem consistent with the results in the literature. The study confirmed what other researchers indicated that in the South Africa the dynamics of rural home gardening expansion may change because of the changing role of household in society due to increased livelihood broadening of agriculture (Elmqvist \& Khatir, 2007).

\subsection{Socio-Economic Characteristics of the Samples}

The samples interviewed were rural male and female farmers who grow seasonal crops for food and cash (see Table 1 the demographic characteristics of the samples) in the study area. The results findings shows that $40 \%$ of the households interviewed were male while female households were $60 \%$ (see Table 1). Therefore females are more dominant in home gardening than men as shown by the results in the table. This is because women spend most of the time taking care of the family while men go to urban areas in search for better employment opportunities. This result agrees with Kehler (2001) that in South African rural areas women play a vital role in agriculture as food producers than men. Overall 44.5\% (male) \& 49.1\% (female) of the respondent fall within the age range of 31-45years which shows that the older men and women are more into home gardens activities. The household that are into garden were $29 \%$ (male) \& 36.2\% (female) fall within the range of (46-60years) while $16.5 \%$ (male) \& 10.4\% (female) were (15-30years). However, 10\% (male) \& 4.3\% (female) were fall under the range (61years and above) respectively. The older household heads (61 and above) still have garden that is under the care of their sons or daughters.

According to Muchara (2010), the household's age is a highly important aspect because it shows whether the household benefit from the experience of the older people or has to base its decisions on the risk taking attitude of younger farmers. This is likely to enhance household food security status because older people are more experienced with agricultural practices (home gardening) and have inherited such knowledge from their forefathers. Marital status of households shows that the majority of respondent interview are married were $70.4 \%$ male \& 65\% female while 20\% male \& 10\% female respondent were single, divorced $8.0 \%$ (male) \& 5.2\% (female). More so, widower respondent interview were $1.6 \%$ male $\& 4.8 \%$ female respectively. This result prove 
Zenda (2000), which stated that married households have advantage because they have partner to work with them in garden. The single household's families are the second largest group followed by the divorced households and finally the widowed are the smallest group. More so households with married people are able to share household activities such as agricultural production, harvesting of fruits, weeding, fetching of firewood and water, while divorcees, single and widowed household heads have to do all the household activities as they do not have all the support unless from their older children who are fit to assist with the household activities Zenda (2002).

The result finding reveal the level of education attained by the household relates to the human capital as well as the ability to cope with modern farm decision making processes. According to Muchara (2010) the people who have higher educational level are able to interpret information better. Illiteracy is one of the factors that limit economic, social, physical, technical and educational development in less developed countries (Bester et al., 1999). In this study the level of education ranges from those who do not have any formal education to those who attained tertiary education. The respondent that had secondary education was $30 \%$ male \& $27.4 \%$. The number of households that had primary education was $41.5 \%$ male \& $50 \%$ female. Most of these respondents that had tertiary education were $22.3 \%$ male \& $5 \%$ female. However, $6.2 \%$ male \& $17.3 \%$ of the respondent had no formal school education but were also actively involved in home gardening.

Table 1. The main characteristics of the sample surveyed

\begin{tabular}{lll}
\hline & Male & Female \\
\hline Sample size & $40 \%$ & $60 \%$ \\
Marital status (\%) & & \\
Single & $20 \%$ & $10 \%$ \\
Married & $70.4 \%$ & $65 \%$ \\
Divorced & $8.0 \%$ & $5.2 \%$ \\
Widower & $1.6 \%$ & $4.8 \%$ \\
Education (\%) & & \\
No school & $6.2 \%$ & $17.3 \%$ \\
Primary school & $41.5 \%$ & $50.0 \%$ \\
Secondary school & $30.0 \%$ & $27.4 \%$ \\
Tertiary & $22.3 \%$ & $5.3 \%$ \\
Age Distribution (\%) & & \\
$15-30$ & $16.5 \%$ & $10.4 \%$ \\
$31-45$ & $44.5 \%$ & $49.1 \%$ \\
$46-60$ & $29.0 \%$ & $36.2 \%$ \\
$60+$ & $10.0 \%$ & $4.3 \%$ \\
\hline
\end{tabular}

\subsection{Major Crops Grown in Home Gardens in the Study Area}

The crops grown in the study areas are shown in Figure 1, that there was no evidence of new crops or vegetables at study area from the data collected during this investigation. One of the characteristics of food insecurity in rural areas is lack of variety of food. Monde (2003) notes that lack of irrigation water prevented households from considering planting various vegetables in home gardens, which means these crops and vegetables mentioned help reduce household food security since these households have access to freshly produced crops and vegetables daily. Major eight crops and vegetables identified; maize, cabbages, carrot, onion, butternut, tomatoes, potatoes and spinach were produced by a larger proportion of households. More so, the following crop and vegetables were planted throughout the season such as; spinach, onion, potatoes and tomatoes, result reveal that household play a significant role in home gardening in the study area. 


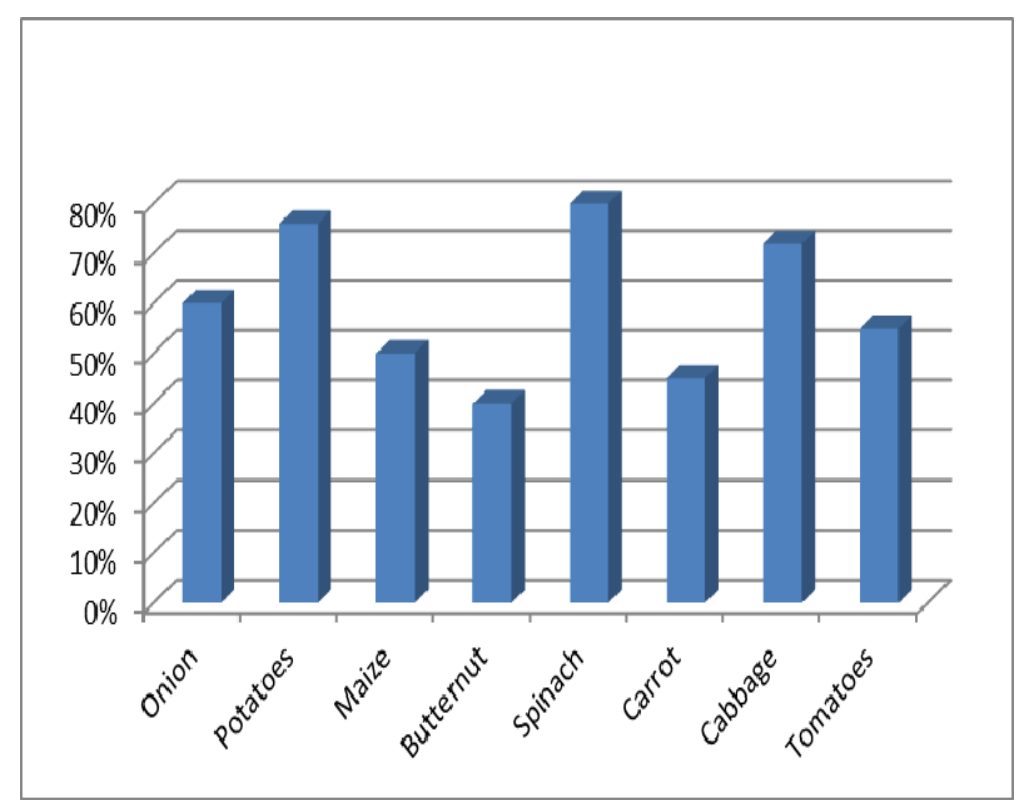

Figure 1. Types crops grown in home gardens

\subsection{Annual Earnings from Vegetable Sale in the Study Area in 2012}

The kinds of vegetables sold by households in the study area are presented in Figure 2. These figures show the different major vegetable groups as well as the total amount earns by individual households during 2012. The result findings reveal the vegetable income by household during 2012 season in the study area were belong to seven major vegetable groups namely; Cabbage, Spinach, Carrot, Onions, Butternut, Lettuce and Green pepper. However, household earns more on cabbage and spinach than other vegetable in all the season because majority of the respondent interview were planted them throughout the season which enable household had access to cabbage and spinach, they also make enough profit at the end of the year.

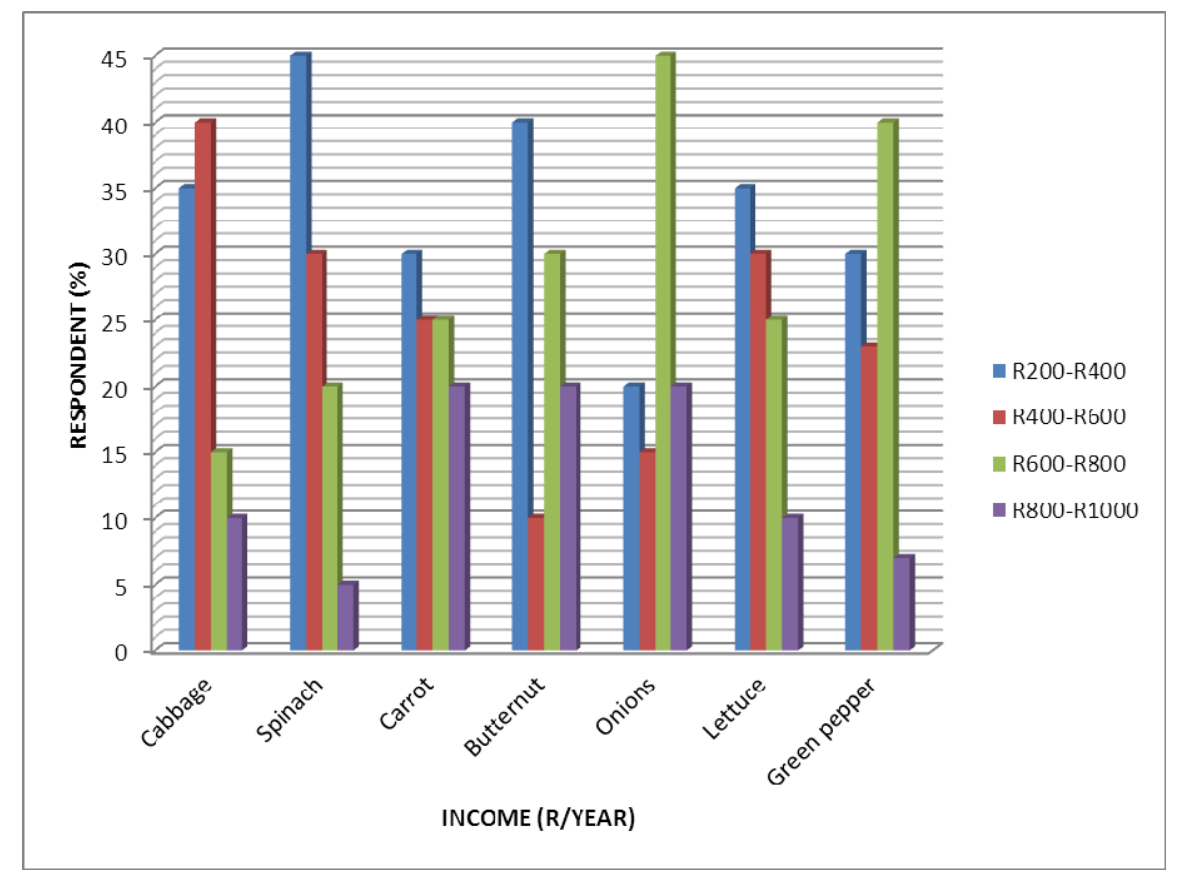

Figure 2. Annual earnings from vegetable sale in the study area in 2012 
The result show that household income earns on vegetable were less during the winter period and these were time the rate of vegetable consumption in household were reduce because during surplus time they don't have means of preserving it due to lack of capital. From Figure 3 above show the different range of money earns from vegetable in study area and the ranges were; R200-R400, R400-R600, R600-800, R800-R1000. Result findings reveal that 40\% of the respondent interview had the highest earns range were R400-R600 on cabbage, $10 \%$ respondents were R800-R100 had the lowest earn while $45 \%$ household earn R200-R400 on spinach and 5\% respondent were R800-R1000.

\subsection{Food Acquisition Strategies by Households in the Study Area}

Households were asked to indicate all the various ways to secure their food. These were found to consist of a combination of food acquisition strategies (i.e. ways of obtaining food) and entitlements. There are different strategies that households adopt for food acquisition in order to feed their household members and that is by buying, own food production or by getting food assistance from other households). The result findings reveals that majority of the respondents interview $60 \%$ were depend on their own production because they had crops and vegetables consumed year round on their farms. Household acquired food through super market in town presented with $30 \%$ and the reason for these were because there some food items that were not planted while $(10 \%)$ respondents interview were acquire food from the local shops within the communities. The percentages of respondents indicate own production has their sources of acquired food in the study area, show that home gardening play a crucial role in household food security.

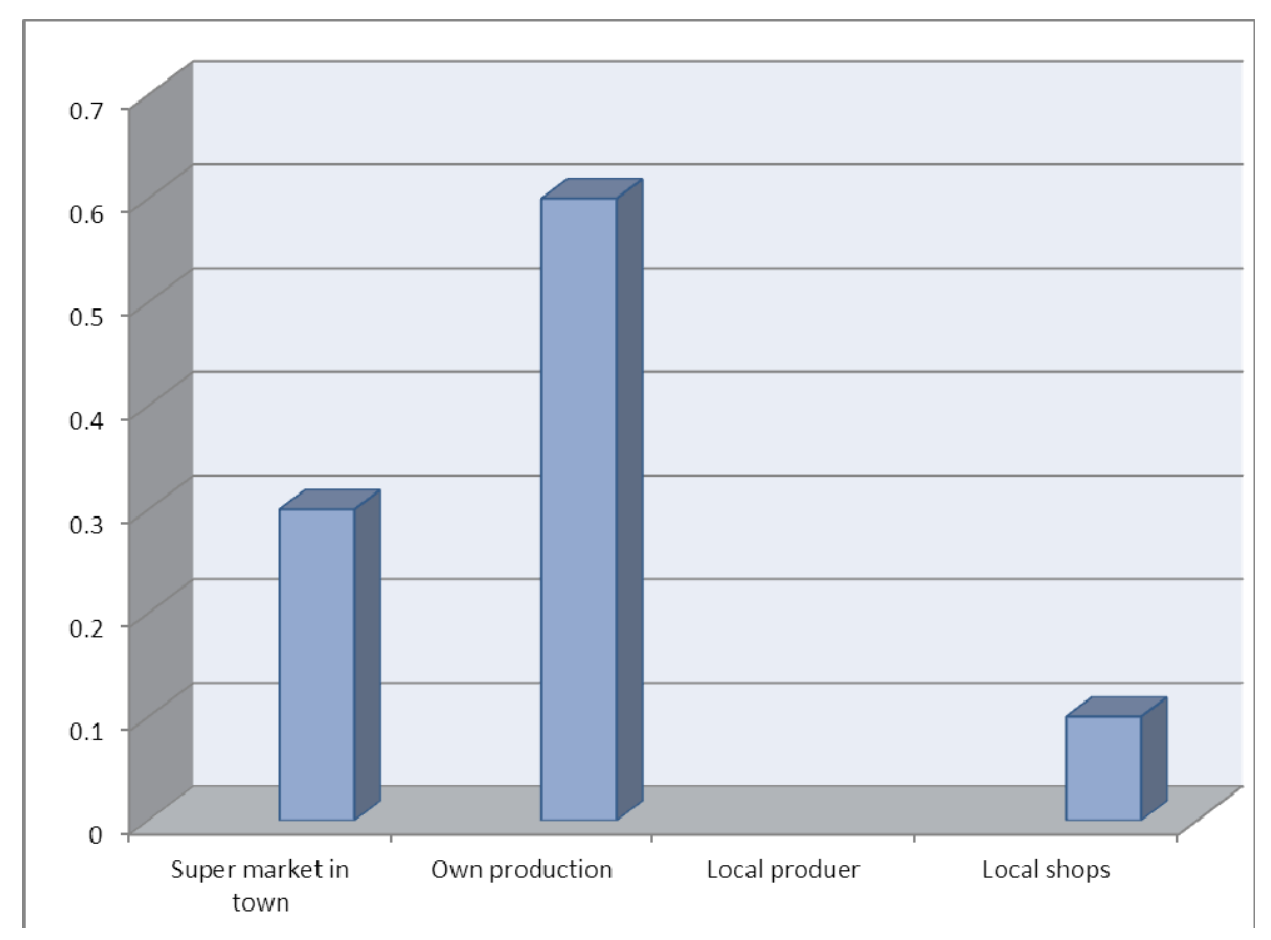

Figure 3. Food sources by households in the study area

\subsection{Sources of Vegetable in the Study Area}

According to Matshe (2009) the hunger problem can be resolved by practicing agricultural activities (food production). This particular focuses on sources of ingredients in rural households that engage in home gardening. Figure 4, present the various ways that household sources for vegetable at different time of the year, there are main three sources which household's use to get their main ingredients such as; own production, Local producer and Supermarket in town. Majority of the household interview based on their own production and they all had spinach, cabbage and onion on their garden throughout the different season of the year were $70 \%$ while $(10 \%)$ of the respondents were used to buy their vegetables from local producer. Most rural households used to buy their vegetables from the supermarket in town were $20 \%$. More so, the results show that rural household in the study area were food secure based on the percentage of the respondent that depend on their produce from the gardening which indicate they had access to food at available time throughout the season. 


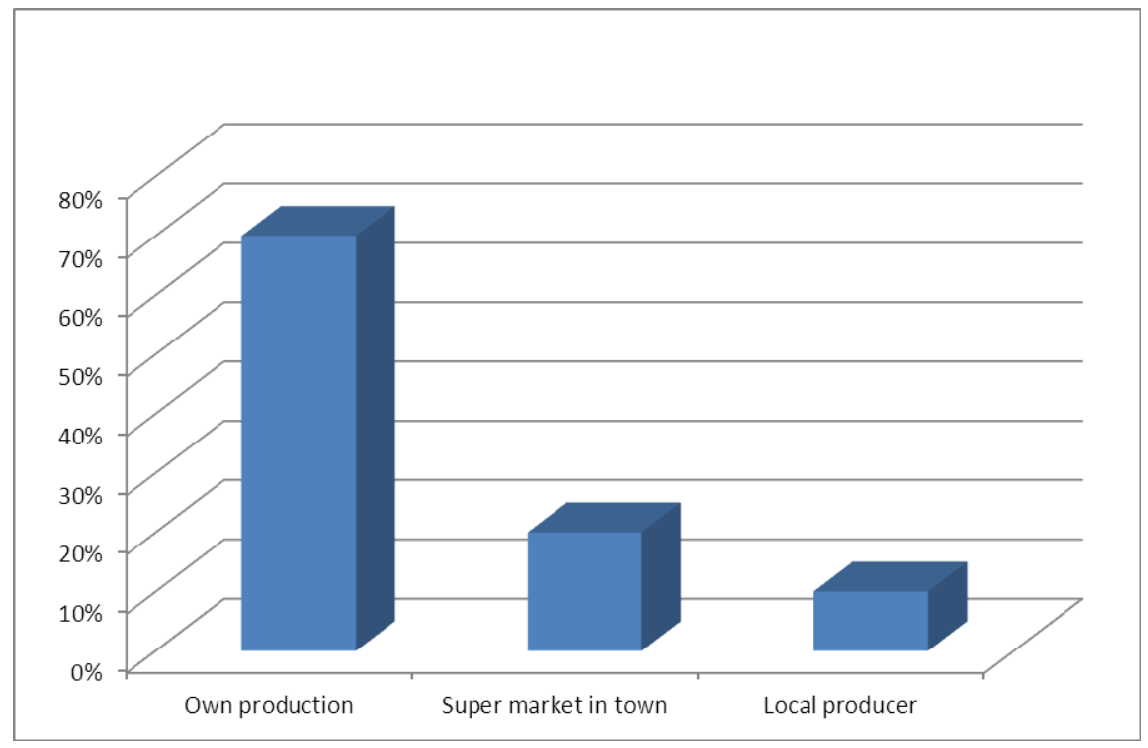

Figure 4. Sources of vegetable in the study area

\section{Conclusion}

Food security in Nkonkobe Municipality of the Eastern Cape Province according to the results of the study shows that home garden play a crucial role in rural household. However improving household income and making use of home gardens will yield a large improvement in agricultural production and reduce household food insecurity. Strategies that enhance household income and practicing of home gardens need more attention when it comes to reducing household food insecurity. Through home gardening the problem of food insecurity can be addressed since households can participate in home gardening in order to supplement their household's food basket. But this can only happen if home gardens can be taken as a strategy to help with the food insecurity problem amongst rural inhabitants.

There are benefits that are attained from engaging in this activity such as employment creation, reduction of household expenditure on food, income generation and recreation. There are constraints as well that prohibit rural and urban households from taking part in home gardening such as lack of land, water and education. Home gardens can be improved through improving education level of household heads, having access to land especially in rural areas where land for home garden is limited. This requires a joint effort of government, municipalities, households, non-governmental organizations and private sector role players.

\subsection{Policy Recommendations}

Regard to role of home gardening in improving household food security revealed by the empirical results, recommendations can be suggested. This section gives a series of options that can be considered in South Africa, in an effort to help home gardening farmers reach their full potential. The smallholder farmers in South Africa are facing unfair competition from the formerly supported commercial farmers. In addition, they are facing competition from internationally imported produce. For example, cheaper produce, due to subsidy policies in developed countries is imported into South Africa. In order to withstand both local and international competition, the South African government needs to consider support policies and regulation that are necessary to stimulate growth among the smallholder and emerging farmers.

It should noted that one of the reason why financial institutions fail to offer loans to smallholder farmers on a sustainable basis is that they consider smallholder to be incompetent because they are not capacitated with the skill to utilized such loans efficiently. Government-created institutions may be helpful in capacitating smallholder farmers with production and management skills. This will help farmers to utilize their loans more effectively and efficiently. If lending institutions can discover that smallholder enterprises are more sustainable and are able to repay loans, there is no doubt that they will continue providing smallholder farmers with financial assistance. If government can intervene by engaging more development strategies in rural areas so that people can learn more about agricultural activities so that they can participate in farming (home gardens). The government and research institutes need to come up with workshops to train people about home gardens and benefits of engaging in agriculture, better infrastructural development and more agricultural inputs so that people can have access to these 
to produce more and buy less, than to buy more food. The government and farmers support organizations can also provide better infrastructure to these people.

Rural households should be educated on programs to help address the issue of food insecurity which mainly affects rural people than urban people. Household income can be improved by providing skills development initiatives that household members can use and generate income from such as agricultural projects (sheep keeping, goat keeping, bee keeping, cattle and crop farming though the use of water harvesting technologies). The government should invest in education so that school children can be enriched with knowledge and this will in turn lead to reduce the migration of people from rural areas to urban areas in search of better education. Apart from that rural school and people living in rural areas need to be equipped with agricultural information so as to contribute to household food security through understanding the role played by home gardens. Informal training of household members could also improved by sending extension officers to educate household about food security.

\section{References}

Action Aid. (2005). Food security and HIV and AIDS in Southern Africa: case studies and implications for Future policy. Action Aid international Southern Africa Partnership Programed, Johannesburg. Retrieved May 19, 2012, from www.sarpon.org

Aliber, M., \& Hart, T. G. B. (2009). Should subsistence agriculture be supported as a strategy to address rural food insecurity? Aggreko, 48(4), 345. http://dx.doi.org/ 10.1080/03031853.2009.9523835.

Altman, M., Hart, T. G. B., \& Jacobs, P. T. (2009). Household Food Security Status in South Africa, Aggreko, 48(4), 345-361. http://dx.doi.org/ 10.1007/s12571-013-0247-y

Baiphethi, M. N., \& Jacob, P. T. (2009). The Contribution of Subsistence Farming to Food Security in South Africa. Aggreko, 48(4), 342.

Carter, M., \& May, J. (1999). Poverty and Class in rural South Africa. World Development, 27(1), 1-20. http://dx.doi.org/10.1016/S0305-750X(98)00129-6

Department of Agriculture, Forestry and Fisheries (DAFF). (2006). Food insecurity in Sekhukhune, Strategic plan for the Department of Agriculture, 86.

Elmqvist, B., \& Khatir, A. R. (2007). The Possibilities of Bush Fallows with Changing Roles of Agriculture: Analysis Combining Remote Sensing and Interview Data from Sudanese Dry-lands. Journal of Arid Environments, 70(2), 329-243. http://dx.doi.org/10.1016/j.jaridenv.2006.12.018

Food and Agriculture Organization (FAO). (2001). State of Food Insecurity. Food and Agriculture Organization of the United Nations. Rome.

FANPAN. (2006). Food insecurity in Sekhukhune. Retrieved May 22, 2012, From http://www.fanrpan.org/documents/d00498/FIVIMS_Info_Brief1_Food_insecurity_S ekhukhune.pdf

Gari, J. (2004). Agro biodiversity strategies to combat food insecurity and HIV and AIDS impact on rural Africa. Advancing Grassroots responses for nutrition, health and sustainable livelihoods. FAO Population and Development Services, Rome. Retrieved June 10, 2012, from www.org/hivaids

Gautan, R., Sthapit, B., \& Shrestha, P. (2004). The role of home gardens to on-farm agro biodiversity Management and enhancing livelihoods of rural farmers of Nepal. On farm conservation of Agricultural biodiversity in Nepal: managing diversity and promoting its benefits.

Human Science Resources Council (HSRC). (2003). "Mitigation of HIV and AIDS impact through Agricultural and rural Development, success stories and future action. Human Service Research Council (HSRC) Workshop Report. May 27-29. Pretoria South Africa. Retrieved October 8, 2012, from www.sarpn.org

Kirsten, J., May J., Hendriks, S., Lyne M., Machete, C. \& Punts, C. (2003). The Poverty and Food Security Role of Agriculture. Paper Prepared For the Roles of Agriculture International Conference, 22-23 October, 2003, Rome, Italy: Agricultural and Development Economics Division (ESA) of the Food and Agriculture Organization (FAO) of the United Nations.

Koyenikan, M. J. (2007). Perception of Home Garden Potential among Women in Edo South Ecological Zone, Nigeria. Retrieved June 15, 2012, from http://www.sabinet.co.za/abstracts/genbeh/genbeh v5_n1_a3.html

Labadarios, D., Davids, Y. D., Mchaza, Z., \& Weir-Smith, G. (2009). The Assessment of Food Insecurity in South Africa. Retrieved $\quad$ February 203, from http://www.hsrc.ac.za/research/output/outputDocuments/5815LabadariosTheassessmentoffoofinsecurit 
Machete, C. L. (2004). Agriculture and Poverty in South Africa: can agriculture reduce poverty? Retrieved July 16, 2012 from http://cfapp1-docs- public.undp.org/eo/evaldocs1/sfcle/eo_doc_357114047.pdf

Mc Lachlan, M., \& Kuzwayo, P. (1997). Bold Choices: Making the South African Nutrition Strategy Work, Development Paper 128. Development Bank of Southern Africa.

Mgijima, C. (1999). Situational Analysis of Food Security and Nutrition in South Africa. A Speech at the $3^{\text {rd }}$ Session of the International Consultative Conference on Food Security and Nutrition as Human Rights Ransburg South Africa.

Monde, N., Van Averbeke, W., Ainsli, A., Ntshona, Z. M., Fraser, G. C. G., \& Belete, A. (1997). Agriculture and Rural Livelihood in North-West Peddle District. Aggreko, 36(4), 616-625. http://dx.doi.org/10.1080/03031853.1997.9523489

Monde, N. (2007). Obstacles of Agricultural Development in the Communal smallholder sector and Role of Extension service. University of Fort Hare South Africa.

Monde, N., Fraser, G., Botha, J. J., \& Anderson, K. (2006). Making home gardening a viable option in rural areas of South Africa: the case study of Guquka and Khayalethu in central Eastern Cape. Retrieved May 11, 2012, from

http://www.uwsp.edu/cnr/gem/Conference\%20Procceedings/Track5Papers/Monde\%20Track5\%20EMSU\% 20paper\%20FinalComplete.pdf

Moorhead, S., \& Wolmer, W. (2001). Food Security and Environment. In M. Devereux (Ed.), Food Security in Sub-Saharan Africa (pp. 93-116). London: Institute of Development studies, itdg publishers.

Moyo, S. (2003). Agrarian Reform, Rural development and economic policy in Zimbabwe, AIAS.

Msaki, M. M. (2006). Measuring household food security using food intake indicators in rural KwaZulu-Natal. Unpublished (Food Security) paper. University of KwaZulu-Natal, Pietermaritzburg.

Musotsi, A. A., Sigot, A. J., \& Onyango, M. O. A. (2008). The role of home gardens in household food security in Butter division of Western Kenya. African Journal of Food, Agriculture, Nutrition and Development, 8(4), 375-390.

Nkonkobe Municipality. (2006). Nkonkobe Municipality-Integrated Development Plan Review Document 2005/2006.

Nkonkobe Municipality. (2007). Nkonkobe Municipality-Integrated Development Plan Review Document 2006/2007.

Nkonkobe Municipality. (2010/2011). Nkonkobe Municipality-Integrated Development Plan Review Document 2010/2011.

Nordin, S. (2005). Per culture Network of Malawi. Personal communication with Stacia Nordin World Food Program, Malawi, November 2005.

Omotesho, O. A., Adewumi, M. O., \& Fadimula, K. S. (2007). Food security and poverty of the rural households in kwara state, Nigeria. Retrieved March 6, 2012, from http://ideas.repec.org/p/ags/aaae07/52203.html

Sen., A. (1981). Poverty and Famine: An essay on entitlement and deprivation. Oxford: Clarendon Press.

Seti, S. (2003). Subsistence Gardening for Food Security: A Case Study of Three Township in Graham's town, Eastern Cape Province. Retrieved May 9, 2012, from http://docs.google.com/viewer?a=v\&q=cache:qkkBVWyju0J:www.fhiser.org.za/Workingpapers/53Set

Thrupp, L. A., \& Megateli, N. (1999). Critical Links: Food security and the environment in the Greater Horn of Africa. WRI Project Report. WRI (World Resources Institute), Washington, DC, and ILRI (International Livestock Research Institute), Nairobi.

Todaro, M. P., \& Smith, S. C. (2000). Intermediate Microeconomics (9th ed.). Alan, USA. PLS.

\section{Copyrights}

Copyright for this article is retained by the author(s), with first publication rights granted to the journal.

This is an open-access article distributed under the terms and conditions of the Creative Commons Attribution license (http://creativecommons.org/licenses/by/3.0/). 